\title{
慢性中耳炎の再手術例の検討
}

\author{
村田 清高・西本力 \\ 原田昌彦・太田 文彦
}

\section{Reoperation Surgery for Chronic Otitis Media}

\author{
Kiyotaka Murata, Chikara Nishimoto, \\ Masahiko Harada and Fumihiko Ohta
}

(Kinki University)

\begin{abstract}
Reoperation was performed on 76 patients with chronic otitis media during a tenyear period. The annual incidence of reoperation in patients undergoing middle ear surgery was between 12 and $17 \%$. In $38 \%$ of the cases, no dry ears were detected following the initial/previous surgery. A dry ear, once occurring rarely recurred within a year following the previous surgery. In 9 ears, the same bacteria were found both before the previous operation and at the time of reoperation. Nine patients underwent tubo-tympanoplasty procedure. Retraction cholesteatoma was found in 7 ears without previous cholesteatoma.
\end{abstract}

Key words: reoperation, dry ear, tubo-tympanoplasty, retraction cholesteatoma

はじめに

耳の手術は術後再発とそれに続く手術手技の 改善という図式を繰り返しながら進少してき た。 近年とくに中耳腔再建術や外耳道後壁再建 術が考案され実施されている(12)314. その意味 で再手術症例の実態は常に変遷していく筈であ り，常に検討されなければならない(5)6)．筆者 ら屯耳珠軟骨板による中耳腔の再建術78) やシ

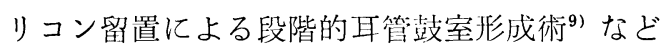
を考案し採用してきた。これらの手術手技の意 義を含めて, 初回手術の問題点を再手術の立埸 から考えてみたい。

\section{調査対象}

近畿大学医学部耳鼻咽喉科学教室において炤 和 52 年 5 月初めから同 60 年 4 月末日までの間に
施行された再手術例は76耳である。男43耳, 女 33耳, 右41耳, 左35耳で, そのうち本院で初回 手術を施行したもの29耳, 他院で初回手術を行 い再手術を本院で行ったもの47耳である，意図 的に 2 段階に分けた手術は再手術に含めず，後 述の 3 つの目的が達せられず再び初期の手術を やりなおしたものを再手術として検討した. 再 手術の再手術すなわち 3 回のものが 4 耳含まれ ていた.

本文ではWullstein の原分類に沿って鼓空形 成術を分類した。鼓室形成術 III 型の原型は Wullstein の III 型原法を（以下III-O型と記 す)，部分コルメラはいわゆるコルメラ而型を (以下III- $\mathrm{P}$ 型と記す)， 全コルメラはアブミ 骨上部構造消失例でアブミ骨底板においたコル 
メラを意味しいわゆるIV型変法 ${ }^{10)}$ を（以下IIIT型と記す）意味している.

\section{結 果}

1. 再手術症例の年踰, 性別

図 1 に示すように20歳未満までは男に多い (12耳/14耳).

2. 中耳手術に占める再手術の頻度

炤和 55 年の $23.5 \%$ をピークに12〜17\%を占め ている（図 2 ）。上記期間における中耳手術の 総数に対する再手術の敖合は76耳/546耳（14 \%)であった。

3. 初回手術後再発までの期間

術後一度も治癒 dry ear に至らなかったも のが29耳 (38\%) に達している（図 3 で0-). そのうち 9 耳 $(31 \%)$ は open technique で ある.耳小骨速鎖再建法による差もない。術後 6 力月〜 1 年は再発が少ない。再発までの期間 は $1 〜 20$ 年に及んでいる.

4. 再手術の目的

耳漏61耳, 真珠腫35耳, 難恥11耳, メマイ 5 耳, 耳重感 3 耳などが主な目的である。そのほ かに顔面神経休痺, 耳鳴, 味覚異常で点検をか ねた再手術耳がそれぞれ 1 耳ずつあった。

5 . 耳漏よりの検出菌

表 1 に示す如く初回手術前13菌種36菌株, 再 手術前17菌種86菌株が検出された。両者に同一 菌が検出されたものは 9 耳であった。

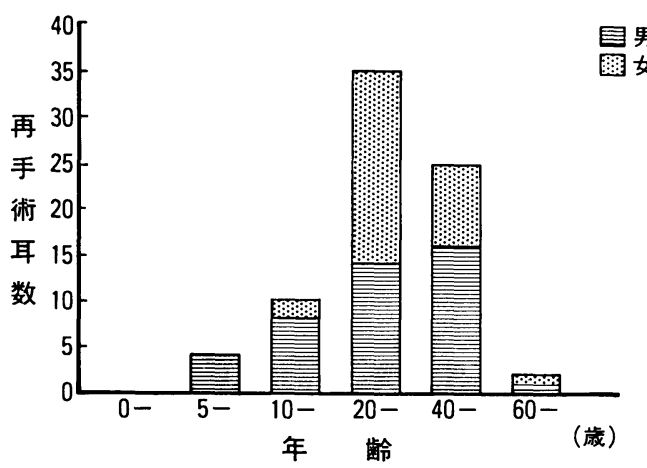

図 1 再手術症例の年秢・性別
6. 初回手術術式

鼓室形成術 I 〜III型が再手術に占める割合は （表 2 ）本院例では24耳/29耳 $(83 \%) ，$ 他院例 では11耳/47耳（23\%）で本院例が $5 \%$ の危険 率で有意に多い（ $x^{2}$ 検定），全体で $46 \%$ を占め る. 但し，他院での初回手術術式は再手術時の 所見より推定した。中耳根本術が再手術に占め る制合は $18 耳 / 76 耳 （ 24 \% ）$ でその $15 耳 / 18 耳$ （83\%）は他院で行われており，本院の例より $10 \%$ 危険率では有意に多い $\left(x^{2}\right.$ 検定)。不明 例が21耳あった。表 2 中の*は初回手術で開放 したか術後破壊されたか不明の 3 耳を含む。

7. 再手術術式

表 3 に示すように鼔室形成術 I 〜III型は29耳 $/ 76 耳(38 \%)$, 中耳根本術は27耳/76耳 (36 \%）で初回手術と有意の差を認めない（ $x^{2}$ 検 定)。初回に中耳根本術で再手術屯根本術が施

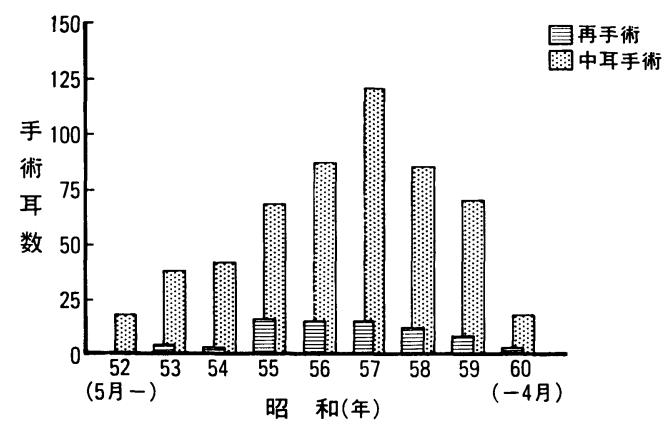

図 2 中耳手術に占める再手術の頻度

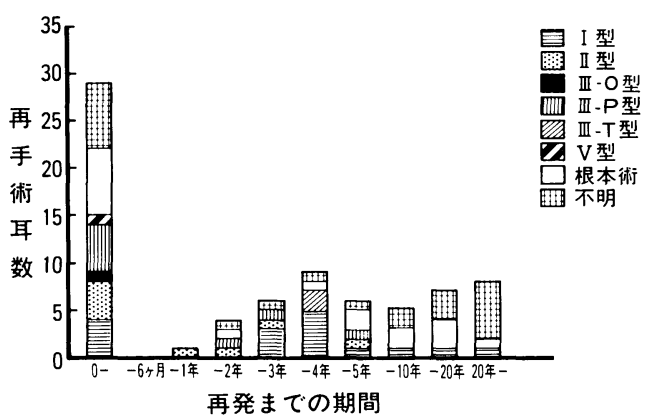

図 3 初回手術後再発までの期間 
表 | 耳漏よりの検出菌

\begin{tabular}{|c|c|c|c|c|}
\hline \multirow{2}{*}{ 菌 } & \multicolumn{2}{|l|}{ 菌 } & \multicolumn{2}{|c|}{ 同一菌検出 } \\
\hline & 初回手術前 & 再手術前 & 耳 & 数 \\
\hline Proteus mirabilis & 9 & 7 & & 2 \\
\hline Proteus inconstans & 6 & 2 & & 1 \\
\hline Staphylococcus aureus & 4 & 16 & & 1 \\
\hline Corynebacterium & 4 & 16 & & 2 \\
\hline Pseudomonas aeruginosa & 3 & 10 & & 1 \\
\hline Staphylococcus epidermidis & 3 & 11 & & 1 \\
\hline E. coli & 1 & 3 & & 1 \\
\hline Streptococcus faecalis & 1 & 2 & & 0 \\
\hline H. influenzae & 1 & 0 & & 0 \\
\hline Candida parakrusei & 1 & 2 & & 0 \\
\hline Morganella morganii & 1 & 0 & & 0 \\
\hline negative & 1 & 2 & & 0 \\
\hline Aspergillus & 1 & 3 & & 0 \\
\hline Providencia stuartii & 0 & 4 & & 0 \\
\hline Candida albicans & 0 & 2 & & 0 \\
\hline Proteus vulgaris & 0 & 1 & & 0 \\
\hline Acinetobacter & 0 & 1 & & 0 \\
\hline$\alpha$-streptococcus & 0 & 1 & & 0 \\
\hline Lactobacilli & 0 & 1 & & 0 \\
\hline Yeast like body & 0 & 2 & & 0 \\
\hline 計 & 36 & 86 & & 9 \\
\hline
\end{tabular}

表 2 中耳再手術症例の初回手術

\begin{tabular}{|c|c|c|c|c|c|}
\hline \multirow{2}{*}{ 初回手術術式 } & \multirow{2}{*}{ 耳数 } & \multicolumn{2}{|c|}{ 乳突削開創 } & \multirow{2}{*}{ 本院 } & \multirow{2}{*}{ 他院 } \\
\hline & & 開放 & 閉鎖 & & \\
\hline \multirow{3}{*}{$\begin{array}{r}\text { 鼓室形成術 I 型 } \\
\text { II 型 } \\
\text { III 型 }\end{array}$} & 12 & 2 & 10 & 5 & 7 \\
\hline & 8 & & 8 & 7 & 1 \\
\hline & & & & & \\
\hline \multirow{3}{*}{$\begin{array}{l}\text { (原 型) } \\
\text { (部分コルメラ) } \\
\text { (全コルメラ) }\end{array}$} & 1 & 1 & & & 1 \\
\hline & 13 & & 13 & 11 & 2 \\
\hline & 1 & & 1 & 1 & \\
\hline $\begin{array}{r}\text { （全コルメラ） } \\
\text { N 型 }\end{array}$ & 1 & 1 & & 1 & \\
\hline V 型 & 1 & 1 & & 1 & \\
\hline 中耳根本術 & 18 & 18 & & 3 & 15 \\
\hline 不明 & 21 & $*$ & 18 & & 21 \\
\hline 計 & 76 & 26 & 50 & 29 & 47 \\
\hline
\end{tabular}


行されたものは15耳/18耳（83\%）であった。 その他段階的鼓空形成術 3 耳，段階的耳管鼓室 形成術 9 耳（12\%）を採用している. 再手術に 中耳根本術を行った 27 耳の初回手術術式は攱室 形成術 I 型 1 耳, I型 2 耳, III $-\mathrm{P}$ 型 1 耳, IV 型 1 耳, V型 1 耳, 中耳根本術15耳および不明 6 耳であった。

8. 初回手術術式と再手術時の真珠腫

再手術で真珠腫が発見された40耳について検 討した（表 4)。乙のうち本院手術例は15耳 /40耳（38\%）であった。本院での初回手術時 に真珠腫がなかったのは 4 耳/15耳（27\%）で あった。本院初回手術例15耳の初回手術の内訳 は I 型 3 耳， I型 3 耳， III $-\mathrm{P}$ 型 8 耳，中耳根 本術 1 耳である。

\section{9. 耳漏の原因病巣}

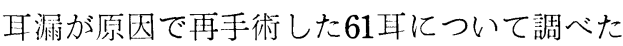
（表 5 )。耳管鼓室口43耳，上鼓空45耳，下站 室・正円空窝47耳，乳突洞全体 37 耳，鼓空洞 31 耳および迷路後部，隅角蜂巣などに原因病巣を 確認した。

10．再手術所昌により判断した初回手術の閣 題点

初回，再手術と屯に本院で手術した29耳につ いて，初回手術将の閌題点を再手術所见より判
断した（表 6 ). 初回手術 I〜III型で再手術で 真珠腫残存と判断したものは 8 耳/24耳（33 \%)でいずれも後壁保存例である. retraction cholesteatoma と判断されたもの 7 耳 $/ 24$ 耳 (29\%) で I ， II 型と III 型との間に有意养をみ ない. 耳管狭窄と判断したものは 4 耳であっ た。 29 耳全体をみると, 病巣削開不足 6 耳, 外 耳道後壁残存部が高過ぎるもの 4 耳, 再感染 3

表 3 中耳再手術症例の再手術術式

\begin{tabular}{|c|c|c|c|}
\hline \multirow{2}{*}{ 再手術術式 } & \multirow{2}{*}{ 耳数 } & \multicolumn{2}{|c|}{ 乳突削開創 } \\
\hline & & 開放 & 閉鎖 \\
\hline \multicolumn{4}{|l|}{ 鼓室形成術 } \\
\hline I 型 & 7 & 2 & 5 \\
\hline II 型 & 3 & & 3 \\
\hline III-O型 & 1 & & 1 \\
\hline III - P 型 & 14 & 7 & 7 \\
\hline III-T型 & 4 & 4 & \\
\hline IV 型 & 1 & 1 & \\
\hline $\mathrm{V}$ 型 & 3 & 3 & \\
\hline 段階的手術 & 12 & 11 & 1 \\
\hline 中耳根本術 & 27 & 27 & \\
\hline 乳突削開術 & 4 & 2 & 2 \\
\hline 合計 & 76 & 57 & 19 \\
\hline
\end{tabular}

表 4 初回手術術式と再手術時の真珠腫

\begin{tabular}{|c|c|c|c|c|c|c|c|c|c|c|}
\hline \multirow{3}{*}{ 術式 } & \multirow{2}{*}{\multicolumn{3}{|c|}{$\frac{\text { 初回手術 }}{\text { 真珠腫 }}$}} & \multicolumn{3}{|c|}{ 再 } & 手 & \multicolumn{3}{|c|}{ 術 } \\
\hline & & & & \multicolumn{2}{|r|}{ 真 } & 珠 & 確 & 認 & \multicolumn{2}{|c|}{ 所 } \\
\hline & 有 & 無 & 不明 & 耳管口 & 正円空窩 & 鼓室洞 & 下鼓室 & 中鼓室 & 上鼓室 & 乳突洞 \\
\hline 鼓室形成術 & & & & & & & & & & \\
\hline I 型 & 4 & 1 & & & & & & 1 & 3 & 3 \\
\hline II 型 & 3 & 1 & & 1 & 2 & 3 & 4 & & 4 & 3 \\
\hline III-O型 & 1 & & & & & & & & 1 & 1 \\
\hline III $-\mathbf{P}$ 型 & 5 & 4 & & & & 1 & 1 & 1 & 8 & 6 \\
\hline III-T型 & & & & & & & & & & \\
\hline IV 型 & 1 & & & & & 1 & 1 & & 1 & \\
\hline 中耳根本術 & 1 & & 6 & 1 & 1 & 2 & 2 & 2 & 3 & 6 \\
\hline 不明 & 2 & & 11 & 3 & 1 & 4 & 2 & 3 & 9 & 10 \\
\hline
\end{tabular}


耳などが考えられた。

11. 難聴が主訴の再手術耳の伝音系

再手術後聴力損失が $30 \mathrm{~dB}$ 以内に達した成功 例は 3 耳/11耳（27\%）と低加た。但し，中 耳根本術 3 耳を含んでいる。耳小骨連鎖の異常
所見では，ずれ 2 耳，部分的消失による離断 5 耳, 固着 3 耳が確認された。

12. 再手術例の術前術後聴力

再手術後気等骨導差 $20 \mathrm{~dB}$ 以内あるいは気導 聴力損失 $30 \mathrm{~dB}$ 以内を成功例とすると 26 耳であ

表 5 耳漏の原因病巣

\begin{tabular}{|c|c|c|c|c|}
\hline & 肉芽 & ポリープ & 粘膜肥厚 - 浮腫 & 真珠腫 \\
\hline 上鼓室 & 17 & 3 & 2 & 23 \\
\hline 下鼓室・正円空窩 & 18 & 15 & 5 & 9 \\
\hline 耳管鼓室口 & 19 & 11 & 8 & 5 \\
\hline 鼓室洞 & 15 & 2 & 5 & 9 \\
\hline 中鼓室 & 8 & 4 & 1 & 5 \\
\hline 乳突洞 & 9 & 1 & & 27 \\
\hline \multicolumn{5}{|l|}{ 蜂巣 } \\
\hline 迷路上部 & 1 & & & \\
\hline 迷路後部 & 6 & & & \\
\hline 尖部 & 2 & & & \\
\hline 顔神周囲 & & & & \\
\hline 隅角 & 9 & & & \\
\hline $\mathrm{S}$ 状静脈洞周用 & 4 & & & \\
\hline
\end{tabular}

表 6 初回手術の問題点

(再手術所見よりの判断)

\begin{tabular}{|c|c|c|c|c|c|c|c|c|c|c|}
\hline & \multicolumn{4}{|c|}{ 初回手術術式 } & \multicolumn{6}{|c|}{ 再手術所見よりの判断 } \\
\hline & \multicolumn{2}{|l|}{ 後 } & \multicolumn{2}{|c|}{ 真 珠 腫 } & \multirow{2}{*}{ r. c. } & \multirow{2}{*}{ 耳管狭窄 } & \multirow{2}{*}{ 削開不足 } & \multirow{2}{*}{$\begin{array}{l}\text { 真珠腫 } \\
\text { 残 存 }\end{array}$} & \multirow{2}{*}{$\begin{array}{l}\text { 後壁の } \\
\text { 残り高い }\end{array}$} & \multirow{2}{*}{ 再感染 } \\
\hline & 保存 & 除去 & 有 & 無 & & & & & & \\
\hline 鼓室形成術 & & & & & & & & & & \\
\hline I 型 & 4 & 1 & 2 & 3 & 2 & & 1 & & & 2 \\
\hline $\begin{array}{r}\text { II 型 } \\
\text { III-O型 }\end{array}$ & 7 & & 4 & 3 & 1 & 2 & 3 & 3 & 1 & \\
\hline III - P 型 & 10 & 1 & 8 & 3 & 4 & 2 & & 4 & & 1 \\
\hline III-T型 & 1 & & 1 & & & & & 1 & & \\
\hline $\mathrm{IV}$ 型 & & 1 & 1 & & & & & 1 & & \\
\hline $\mathrm{V}$ 型 & & 1 & 1 & & & & & & 1 & \\
\hline 中耳根本術 & & 3 & 2 & 1 & & & 2 & & 2 & \\
\hline 合 計 & 22 & 7 & 19 & 10 & 7 & 4 & 6 & 9 & 4 & 3 \\
\hline
\end{tabular}

r. c. : retraction cholesteatoma 
った（表 7 ）。中耳根本術を除いた 49 耳の $53 \%$ に相当している.

13. 再手術耳の反対侧聴力

再手術耳の反刘側に聴力障害を認めたものは
表 8 亿示すごとく 34 耳 $/ 76$ 耳 $(45 \%)$, 両耳と に同じ型の骨尊障害を認めたものは 3 耳のみで あった。恥力型は高音急墜 5 耳, 高音漸傾 4 耳, dip 型 5 耳, 襲 3 耳, 伝音障害のみ 12 耳な

表 7 再手術耳の術前術後聴力

\begin{tabular}{|c|c|c|c|c|c|c|}
\hline & \multicolumn{4}{|c|}{ 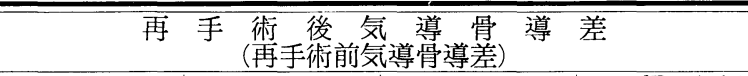 } & \multirow{2}{*}{ 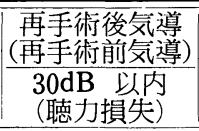 } & \multirow{2}{*}{ 再手術耳数 } \\
\hline & $10 \mathrm{~dB}$ 以内 & $20 \mathrm{~dB}$ 以内 & $30 \mathrm{~dB}$ 以内 & $\begin{array}{l}\text { 30dB を超 } \\
\text { えるもの }\end{array}$ & & \\
\hline \multicolumn{7}{|l|}{ 鼓室形成術 } \\
\hline I 型 & ( 1$)$ & $\left(\begin{array}{l}3 \\
2\end{array}\right)$ & $\left(\begin{array}{l}2 \\
1\end{array}\right)$ & $\stackrel{2}{(1)}$ & $\left(\begin{array}{l}4 \\
3\end{array}\right)$ & 7 \\
\hline II 型 & 1 & $\left(\begin{array}{l}1 \\
1\end{array}\right)$ & ( 1$)$ & $\left(\begin{array}{l}1 \\
1\end{array}\right)$ & $\left(\begin{array}{l}2 \\
1\end{array}\right)$ & 3 \\
\hline III-O型 & & & & $\begin{array}{l}1 \\
(1)\end{array}$ & & 1 \\
\hline III-P型 & $\left(\begin{array}{l}2 \\
1\end{array}\right)$ & 2 & $\left(\begin{array}{l}5 \\
3)\end{array}\right.$ & $\begin{array}{l}5 \\
(9)\end{array}$ & $\begin{array}{l}5 \\
(1)\end{array}$ & 14 \\
\hline III-T型 & & $\left(\begin{array}{l}1 \\
1\end{array}\right)$ & $\left(\begin{array}{l}1 \\
1\end{array}\right)$ & $\left(\begin{array}{l}2 \\
2\end{array}\right)$ & $\left(\begin{array}{l}1 \\
1\end{array}\right)$ & 4 \\
\hline IV 型 & & & $\left(\begin{array}{l}1 \\
1\end{array}\right)$ & & $\left(\begin{array}{l}1 \\
1\end{array}\right)$ & 1 \\
\hline $\mathrm{V}$ 型 & & & 1 & $\left(\begin{array}{l}2 \\
3\end{array}\right)$ & 1 & 3 \\
\hline 段階手術 & $\left(\begin{array}{l}1 \\
1\end{array}\right)$ & 5 & $\begin{array}{l}3 \\
(2)\end{array}$ & $\begin{array}{l}3 \\
(8)\end{array}$ & $\left(\begin{array}{l}6 \\
3\end{array}\right)$ & 12 \\
\hline & $(1)$ & $\left(\begin{array}{l}1 \\
1\end{array}\right)$ & $\left(\begin{array}{l}2 \\
1\end{array}\right)$ & ( 1$)$ & $\left(\begin{array}{l}2 \\
2\end{array}\right)$ & 4 \\
\hline 中耳根本術 & & & & & & 27 \\
\hline 合計 & $\begin{array}{l}5 \\
(4)\end{array}$ & $\begin{array}{l}13 \\
(5)\end{array}$ & $\begin{array}{l}15 \\
(10)\end{array}$ & $\begin{array}{l}16 \\
(26)\end{array}$ & $\begin{array}{c}22 \\
(12)\end{array}$ & 76 \\
\hline
\end{tabular}

表 8 再手術耳の反対側の聴力

\begin{tabular}{|c|c|c|c|c|c|c|}
\hline \multirow{2}{*}{ 聴 } & \multirow{2}{*}{ 力 } & 反 & 対 & 耳 & 病 & 変 \\
\hline & & 活動性中耳炎 & 真珠腫 & & 中耳炎遺残 & 異常なし \\
\hline \multirow{8}{*}{\multicolumn{2}{|c|}{$\begin{array}{l}\text { 高音急墜 } \\
\text { 高音漸傾 } \\
\text { Dip 型 } \\
\text { 竩 } \\
\text { 山型 } \\
\text { 伝音障害のみ } \\
\text { 混合性難聴 } \\
\text { 正常 }\end{array}$}} & \multirow{5}{*}{2} & \multirow{8}{*}{1} & & \multirow[t]{3}{*}{2} & 3 \\
\hline & & & & & & 4 \\
\hline & & & & & & 5 \\
\hline & & & & & \multirow[t]{2}{*}{1} & \\
\hline & & & & & & 1 \\
\hline & & \multirow{3}{*}{$\begin{array}{l}5 \\
2\end{array}$} & & & \multirow{3}{*}{$\begin{array}{l}5 \\
1\end{array}$} & 1 \\
\hline & & & & & & \\
\hline & & & & & & 1 \\
\hline & 計 & 9 & 1 & & 9 & 15 \\
\hline
\end{tabular}


どであった。両側耳を手術したのは 2 人であっ た。 反対側 34 耳の気導聴力損失は $30 \mathrm{~dB}$ 以内 22 耳， $30 \mathrm{~dB}$ 以上 12 耳であった。 この 12 耳の再手 術耳を見ると, 再手術後 $30 \mathrm{~dB}$ 以内へ改善した あのはなかった。 術式は中耳根本術 5 耳, 鼓室 形成術III型の原型 1 耳, III $-\mathrm{P}$ 型 2 耳, III-T 型 1 耳， I 型 1 耳， V 型 1 耳，乳突削開術 1 耳 であった。

\section{考案}

再手術の目的は(1)再発耳漏の停止，(2)再発あ るいは残存真珠腫の除去, (3)聴力改善などであ り, 初回手術の目的々変りはない。特に病巣の 完全な除去とそれに伴い破壊された中耳構造を 再建する方法とが大きなテーマである．近年初 回手術の術式は多様化しており，したがって， 再手術耳の所見および手術手技は多様化してい る. というのは, 外耳道後壁の再建術, 中耳腔 再建術などが近年著しく発展し, 多彩な手術手 技が施行されるようになったからである(12)314 7)899)．再手術耳を検討した結果から注目すべき 点を述べると以下のようになる。

1）初回手術後一度も dry ear にならなか ったものが38\%を占めている（図 3 ）。 そのう ち31\%は open technique である. この原因 としては病巣摘出術の不完全なこと, 術後開放 刢の新たな感染が考えられる，乙の事実は表 1 の耳漏よりの検出菌の結果とも符合している. すなわち, 初回手術前と再手術前とで同一菌種 が検出されたものが 9 耳しかない，後者の事実 については, 術後感染あるいは耳漏よりの検出 菌が中耳内の細菌とは別種であった可能性 ${ }^{1112)}$ 屯考えられる. 初回手術後耳漏の継続する例で は新たな感染あるいは耳内の未検出菌の存在を 念頭において対処すべきてとを示唆している. また術後 6 12力月には再発が見られていな い.とれは一度 dry ear になって半年から一 年の間は再発が少ない事を示している. 術後の 経過観察ではこの期間より以後が大切な事を示 しており，留意したい。

2 ) 初回手術の術式については他院例の半数
が不明なので詳しく言及できないが，中耳根本 術が施行された18耳の再手術が含まれている (表 2 )。本手術の目的加らいって再手術を要 するのは問題である。病巣削開不足，外耳道後 壁残存部の高過ぎおよび再感染などに留意した い.

再手術術式を見ると（表 $3 ） 9$ 耳（12\%）に 筆者らの開発した段階的耳管鼓室形成術 ${ }^{7}$ が行 われている。乙れらの症例に対しては従来の術 式のみから考えると中耳根本術が行われたと予 想される。即ち 27 耳 +9 耳のうち 9 耳 $(25 \%)$ については根本術をせず，新しい手術手技が選 択できたてとを意味している。本手術法の意義 がここに認められる。また筆者らが先に発表し た耳珠軟骨板を用いた中耳腔再建法7) が III$\mathrm{P}$ 型，III一 $\mathrm{T}$ 型に採用されている。再手術例に この 2 つの手術法が新たに採用されている様子 がわかる，炎症性变化による耳管機能不良例沶 よび根本術耳の中再建術に役立っていると言 える。

3 ）初回手術の問題点は真珠腫残存例が鼓室 形成 I〜型ではいずれも外耳道後壁保存例で あったこと，open technique で再手術例では 後壁が高く残存し，開放创の外耳道後壁へのド レナージがうまくいかなかったとと， 7 耳に retraction cholesteatoma が生じたととなど である．最後の例は真珠腫が生じる要因が新た に生じたことを示し医原性ともいえる ${ }^{13)}$. 上皮 の侵入防止に十分留意する必要がある。ちなみ に，残存真珠腫の発見には高空間分解能を屯つ 側頭骨 C T が威力を発揮する ${ }^{14)}$.

4 ）難聴が主訴で再手術を行った11耳の術後 聴力をみると成功例に入るのは 3 耳/ $11 耳 （ 27$ \%) 之低い，元来骨導の著朋な低下があり成功 基準に達し難いものが含まれていることも関係 するが，単に耳小骨連鎖，鼓膜の異常を改めた だけでは聴力が改善しない可能性のあることを 示している。このうち中耳根本術 3 耳を除いた 残りの 8 耳のうち 3 耳は descending linear の 骨導， 1 耳に linearに近い例を含んでいた。こ 
机は Schuknecht ${ }^{15)}$ の conductive cochlear presbycusis 亡類似の所昌である。すなわち, 内耳の其鳴機桠に mechanical な障帮を令ん でいる问能性がある。このような例は単なる川

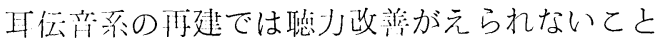
になる，前庭空，蝸牛空の処置にも留意すべき である。また，術前に蝸牛内の伝音障軋を于ェ ックするお法む考えておか权ばならない.

5 ）根本術を除いた再手術耳の術後埴力で成 功例の基準に入るのは $53 \%$ あるる。㮩力改善を 再手術の主要な目的に入れてよい.

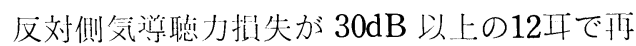
手術开屯術後 $30 \mathrm{~dB}$ 以内へ改着したものがなか

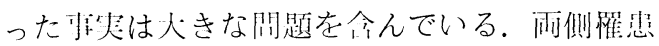
耳は揌力改源の成績が琹いという報告と一致し ているが揌力改善の目的はこのような例にこそ

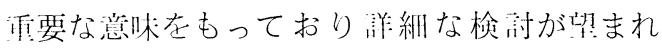
る。そのためには前なる鼓脱，开小骨に対する

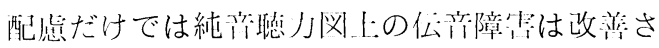
れないことも多いので，考穼4）で还べた棒 と考え介せて刘処することが大切である。

\section{まとめ}

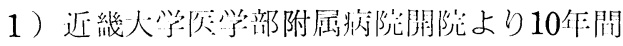
の再丁術耳76मについて众时した。中耳手術総 数に対する制介は76丩/546丩（14\%只）であっ た。

2 ）初同手術後一度屯 dry ear にならなか ったむのが38\%をけけなた。のうち そ1\%は open technique であった。一度 dry ear が えられると一作間は再発が少ない。

3）初回手術前再手術前之同一の菌が検出さ れたものは 9 耳にすぎなかった。

4) 篚者らの仮称段階的耳管政空形成術は 9 耳（再手術例の $12 \%$ ) 飞行われており, 従来の 術式では中耳根本術を行ったと思われるむのの 25\%にあたる。

5) 7 耳に retraction cholesteatoma が生 じたことで特に注意を喚起した。

6 ）根本術孝除いた再于術耳の術後恥力成功

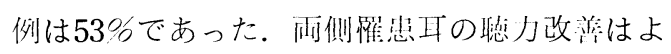

くなかった。

本論文の要旨は第12回日本臨床耳科学会（東京， 1984）において発表した。

\section{参考文献}

1) Palva $T$ : Reconstruction of ear canal in surgery for chronic ear. Arch Otolaryngol $75: 329 \sim 334,1962$.

2) Perkins R: Tympanomastoid reconstruction : An operative procedure for anatomical and functional restoration of the radicalized ear. Laryngoscope $86: 416 \sim 430,1976$.

3 ）柳原尚明, 他：鼓室成形再手術における耳珠軟骨 の利用. 耳鼻臨床 $72: 613 \sim 618,1979$.

4) 鈴木游一, 他：根治手術中耳の鼓室・乳突洞の再 建. 耳舅臨床 $69: 1665 \sim 1671,1976$.

5 ）森湍 保：鼓室成形術, 再手術例の検討. 耳鼻 12: 201 205, 1966.

6 ）風閴保彦：鼓室成形術不成功例の反省. 耳鼻臨床 68: 357 359, 1975.

7) Murata $\mathrm{K}$ and Ohta $\mathrm{F}$ : Reconstruction of the middle ear with tragal cartilage. Acta Otolaryngol Suppl 4l9:130 135, 1985.

8 ）村田清高: 鼓室, 乳突洞の再建一耳珠軟骨板の応 用一. 耳鼾臨床 $72: 619 \sim 625,1979$.

9) Murata $K$ and Ohta $F$ : Reconstruction of the eustachian tube and the anterior tympanum: Planned staged tubo-tympanoplasty. Laryngoscope $95: 330 \sim 334,1985$.

10）中耳炎とその後遺症に対する手術法の分類と名 称．オトマイクロサージャリ一研究会, 手術用語 委員会, 1972 .

11）森弘，他：慢性中耳炎之細菌の動態一その背 後にある $2 \sim 3$ の問題点一. 耳鼻臨床 $63: 3$ 〜 $10,1970$.

12）村田清高, 他：アブミ骨上部構造消失例の臨床 像. 耳鼻臨床 $75: 1355 \sim 1364,1982$.

13）㰒 正芳, 他：中耳の再手術一理論と実際一。 日 耳鼻 $85: 47 \sim 54,1982$.

14）村田清高, 他：側頭骨 C T 亿上万臨床診断. 耳鼻 臨床 $76: 424 \sim 434,1983$.

15) Schuknecht HF : Pathology of the ear. A 
Commonwealth Fund Book (ed by Schukunecht HF). pp 398 403, Harvard University

Press, Cambridge, Massachusetts, 1974.

原稿到着：昭和61年 1 月 29 日

別刷請求先：村田清高

T589 大阪府南河内郡狭山町西山 380

近畿大学医学部耳鼻咽喉科学教室 